\title{
MOBILE PHONE USE PATTERN AND SELF REPORTED HEALTH PROBLEMS AMONG MEDICAL STUDENTS
}

\author{
Sumit Datta ${ }^{1}$, Vincy Nelson'2, Sony Simon ${ }^{3}$ \\ ${ }^{1}$ Associate Professor, Department of Community Medicine, Travancore Medical College, Kollam, Kerala. \\ ${ }^{2}$ Assistant Professor, Department of Community Medicine, Travancore Medical College, Kollam, Kerala. \\ ${ }^{3}$ Lecturer and Statistician, Department of Community Medicine, Travancore Medical College, Kollam, Kerala.
}

\section{ABSTRACT}

Pattern of mobile phone use and self-reported health problems related to over use of the mobile phones are assessed among the medical students of Travancore Medical College, Kollam.

\section{MATERIALS AND METHODS}

Study design: Cross-sectional study. Sample size: 200 students; Sampling technique: Convenient sampling; Data analysis: Data was entered in MS Excel and analysed by SPSS 20.

\section{RESULTS}

A total of 200 students and interns participated in the study and among them 78 were males and 122 were females; $33 \%$ of the participants were very frequent users of cell phone ( $>2$ hours in a day); $77 \%$ of students are using smart phones and $23 \%$ using simple phones; $39.5 \%$ of students spending $100-300$ Rs per month to recharge and $34.5 \%$ spending $300-500$ Rs for the same. More than half of the study population (57\%) check their mobile phones every half an hour. Almost $45 \%$ students reported to have earache; headache and blurring of vision are some of the other symptoms reported by them. There is a significant association between the above mentioned health symptoms and frequent use of multimedia in mobile phones. Ringxiety is also significantly associated with frequent use of mobile phones.

\section{CONCLUSION}

There is substantial clue that there is overuse of mobile phones among medical students. Actions must be taken proactively to cut down and limit the mobile phone use.

\section{KEYWORDS}

Mobile Phone Use Pattern, Nomophobia, Cell Phone Addiction, Ringxiety.

HOW TO CITE THIS ARTICLE: Datta S, Nelson V, Simon S. Mobile phone use pattern and self-reported health problems among medical students. J. Evolution Med. Dent. Sci. 2016;5(21):1116-1119, DOI: 10.14260/jemds/2016/259

\section{INTRODUCTION}

There is considerable impact of mobile phones on contemporary society. Ever since it was introduced, the mobile phones had gained increasing popularity for the ease and convenience of communication. There has always been a counter argument and extensive research over the increasing use of mobile phones and its short term and long term health effects. Social scientists have pointed out that overuse of mobile phones can affect social and psychological well-being and health. ${ }^{1}$

Mobile phones are low-powered radiofrequency transmitters with frequencies between 450 and $2700 \mathrm{MHz}$, operating through a network of base stations. ${ }^{2}$ The World Health Organization (WHO) established the International EMF Project in 1996 to evaluate the science, recommend research to fill any gaps in knowledge and to conduct formal health risk assessments of RF exposure.

Although, WHO has categorically stated that there is no known consequence on health below the limits recommended by International Commission on Non-Ionising Radiation

Financial or Other, Competing Interest: None.

Submission 15-01-2016, Peer Review 24-02-2016,

Acceptance 29-02-2016, Published 14-03-2016.

Corresponding Author:

Dr. Sumit Datta,

Associate Professor,

Department of Community Medicine,

Travancore Medical College, Medicity,

Thattamala P. O., Kollam-691020.

E-mail: sumitdatta2@rediffmail.com

DOI: $10.14260 /$ jemds/2016/259
Protection (ICNIRP). The concerns are raised on the issues of overuse of mobile phones and more recently on mobile phone addiction. ${ }^{3}$

With recent introduction of the smart phones researchers noted that addictive behaviour has been shown by the users which is comparable to compulsive gambling and video gaming, having both physical and psychological withdrawal symptoms when they stop using it like anxiety, restlessness, irritability. ${ }^{4}$ Self-reported symptoms associated with using mobile phones most commonly include headaches, earache, warmth sensations and sometimes also perceived concentration difficulties and fatigue.5, 6

A recently introduced term, nomophobia has also attracted considerable amount of attention among the experts. Nomophobia, an abbreviation for "No-mobile-phone phobia," was coined during a 2010 study by the UK Post Office to look at anxieties suffered by mobile phone users. ${ }^{7}$ Clinical characteristics of nomophobia are a considerably decreased number of face-to-face interactions with humans and a growing preference for communication through technologies; keeping the device in reach when sleeping and never turned off; looking at the phone screen frequently to avoid missing any message, phone call or notification also called ringxiety. ${ }^{8}$

The other established health hazard is a significant increase in the risk of accidents when the persons used mobile phones during driving. The time has come to think in proactive terms and to limit the overuse of mobile phones. The pattern of mobile phone use is the preliminary requisite to explore the addictive behaviour and the associated health problems. 
The current study was conducted among a group of medical students to find out the pattern of mobile phone use and self-reported health problems.

\section{OBJECTIVES}

1. To assess the pattern of mobile phone use among the medical students.

2. To find out the self-reported health related problems due to mobile phone use among the medical students.

\section{MATERIALS AND METHODS}

\section{Study Design}

Cross-sectional study.

\section{Study Setting}

Travancore Medical College, Kollam.

\section{Study Population}

Undergraduates and Interns of Travancore Medical College, Kollam.

\section{Sample Size}

200 students and interns. According to a literature review by Pedrero Pérez EJ, et al. mobile phone abuse or addiction ranges from $0-38 \%$ among the young population. ${ }^{9}$ In the current study, a prevalence of $30 \%$ was considered for calculation of sample size keeping in mind that mobile phone use is increasing every day. In that way calculated sample size was $233\left(4 \mathrm{pq} / \mathrm{L}^{2}\right)$ with an allowable error of $20 \%$. Where $\mathrm{p}=30$ and $\mathrm{L}=20 \%$ of p. 233 students and intern were conveniently selected for participation into the study; 20 students did not participate in the study and 13 students did not fill up the questionnaire properly.

\section{Duration of Study}

1 August 2015-1 September 2015.

\section{Sampling Technique \\ Convenient sampling.}

\section{Method of Data Collection}

Pretested structured questionnaire; 20-item self-reported Problematic Use of Mobile Phones (PUMP) scale, which has excellent internal consistency (Cronbach's $\alpha=0.94$ ) is used to prepare the questionnaire. 10 The questionnaire was pilot tested among a group of 25 students before the use. Questionnaire was modified according to the feedback of the pilot study. Modified final version of the questionnaire also has good internal consistency (Cronbach's $\alpha=0.82$ ).

\section{Data Analysis}

Data was entered in MS Excel and analysed by SPSS 20.

\section{RESULTS}

The current study was conducted to assess the pattern of cell phone use among the medical students of Travancore Medical College. A total of 200 students and interns participated in the study and among them 78 were males and 122 were females; $35.5 \%$ of the participants were day scholars and $64.5 \%$ were hostlers; $33 \%$ of the students of study sample were very frequent users of cell phone ( $>2$ hours in a day). There was no significant difference in number of very frequent users among males and females. Among the frequent users of the phones ( $>2$ hour in a day) $53 \%$ were hostlers and $47 \%$ were day scholars.
A 77\% of students are using smart phone, (i.e. a mobile phone with an advanced mobile operating system, which combines features of a personal computer operating system with other features useful for mobile) and $23 \%$ using simple phone (i.e. a telephone that can make and receive calls over a radiofrequency carrier, while the user is moving within a telephone service area); $88 \%$ of the study participants have the internet access facility in their phones; $39.5 \%$ of students spending 100-300 Rs per month to recharge and 34.5\% spending 300-500 Rs for the same. The amount of expenditure for the recharge of the phones is shown in the Table 1.

\begin{tabular}{|c|c|c|}
\hline $\begin{array}{c}\text { Amount Spend for } \\
\text { Recharge }\end{array}$ & Frequency & Percent \\
\hline$<100 \mathrm{Rs}$ & 44 & 22.0 \\
\hline $100-300 \mathrm{Rs}$ & 79 & 39.5 \\
\hline $300-500 \mathrm{Rs}$ & 69 & 34.5 \\
\hline$>500 \mathrm{Rs}$ & 8 & 4.0 \\
\hline Total & $\mathbf{2 0 0}$ & $\mathbf{1 0 0 . 0}$ \\
\hline \multicolumn{2}{|c|}{ Table 1: Table showing Amount } \\
Spent for Recharge in a Month
\end{tabular}

More than half of the study population (57\%) checks their mobile phones every half an hour. This points to the fact that overuse and dependency on mobile phones can have serious problems in the current generation. The frequency of call checking pattern is shown in Figure 1.

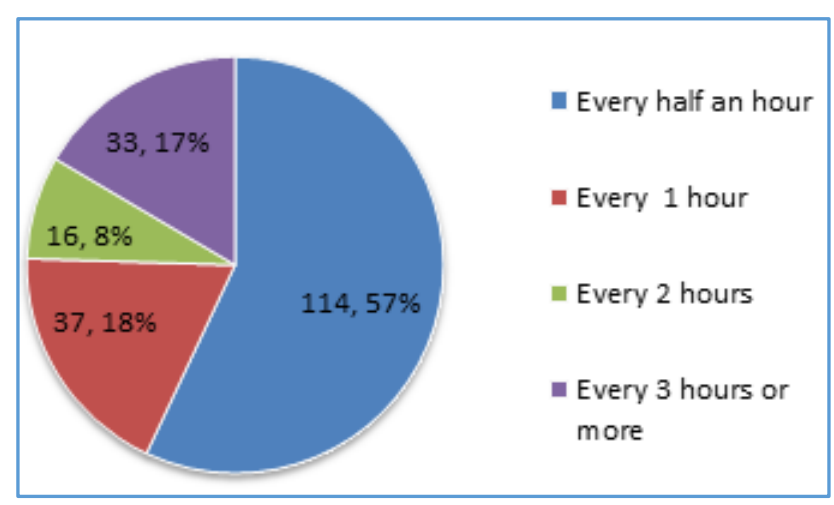

\section{Fig. 1: Frequency of Call Checking among the Study Participants}

Students preferred to call their family (64.5\%) and friends (23\%). About $50 \%$ of students call for sharing information, 39\% for relaxation, $9 \%$ for gossip and 3\% for other purposes. When asked about whether they felt any false perception of ringing, $60.5 \%$ responded yes. This clearly points to the fact that with the use of mobile phone ringxiety is becoming common.

Even though most of the participants had a smart phone, $69 \%$ of them reported that sometimes they got angry with mobile phone, most common reason stated was software problem; $64 \%$ of male participants and $4.1 \%$ female participants had more than one phone and the association of male gender and having more than one phone is significant (Chi square - 85.9; $\mathrm{p}$ value-0.001).

When they receive a call while driving, $47.5 \%$ would not attend, $40.5 \%$ stop vehicle and attend, while $12 \%$ attend while driving. When asked about how will be their life without cell phones, $70 \%$ students answered that they will get bored without cell phones, $24 \%$ will have no effect without cell 
phones; $47 \%$ of the students had reported that they were often warned by somebody for overusing their mobile phones.

It is interesting to note that when enquired about the self-rated addiction to mobile phones, only $22 \%$ of the students responded that they have addiction to mobile phone. Among the students only $7 \%$ knew the meaning of 'Nomophobia.' When probed for self-reported symptoms, almost $45 \%$ students reported to have earache, headache and blurring of vision are some of the other symptoms reported by them. The distribution of symptoms among the study participants is represented in Figure 2.

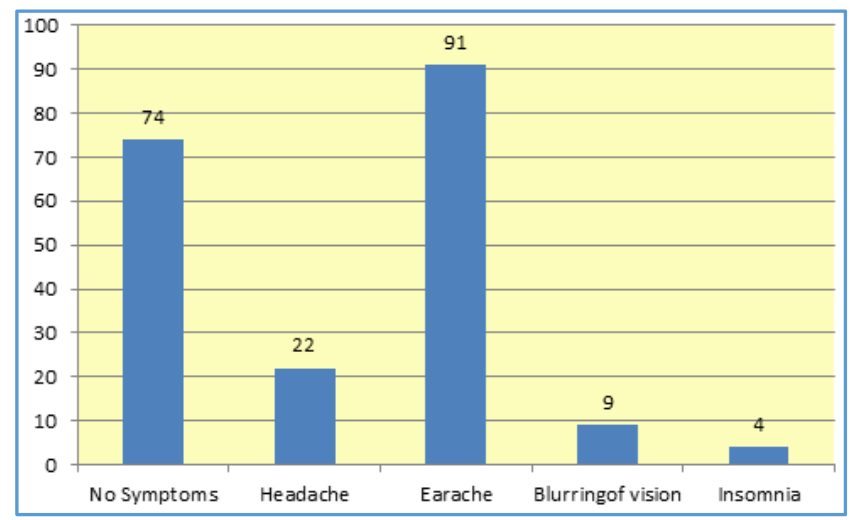

Fig. 2: Distribution of Symptoms related to Overuse of Mobile Phones

There is a significant association between the above mentioned health symptoms and frequent use of multimedia ( $>1$ hour per day) in mobile phones. Ringxiety is also significantly associated with frequent use of mobile phones.

\begin{tabular}{|c|c|c|c|}
\hline \multirow{2}{*}{$\begin{array}{c}\text { Using } \\
\text { multimedia } \\
1 \text { hour or } \\
\text { more per day }\end{array}$} & \multicolumn{2}{|c|}{$\begin{array}{l}\text { Whether they have any } \\
\text { health problem }\end{array}$} & \multirow[b]{2}{*}{ Total } \\
\hline & $\begin{array}{l}\text { No Health } \\
\text { Problems }\end{array}$ & $\begin{array}{l}\text { Have Health } \\
\text { Problems }\end{array}$ & \\
\hline Yes & $16(21.6 \%)$ & $92(73.0 \%)$ & 108 \\
\hline No & $58(78.4 \%)$ & $34(27.0 \%)$ & 92 \\
\hline Total & 74 & 126 & 200 \\
\hline \multicolumn{4}{|c|}{$\begin{array}{l}\text { Table 2: Association between Frequent } \\
\text { Multimedia Use and Health Problems }\end{array}$} \\
\hline
\end{tabular}

Chi square -49.57 , P value -0.001

\section{DISCUSSION}

The present study was conducted among 200 medical students and interns with the objective to find out the pattern of mobile phone use and self-reported health problems. Almost 34\% of the participants used to spend Rs. 300-500 per month for the recharge. Dr. Dharaprajapati et al. reported almost similar pattern of expenditure. According to their findings, 44\% students responded that they spend Rs. 250-500 per month for their mobile recharge, only $6 \%$ spent $<100$ rupees, $22.6 \%$ spent $100-200$ rupees per month, while $27.4 \%$ student spent more than 500 rupees per month for mobile recharge. 11

$77 \%$ of the students had a smart phone. Frequency of call checks, which points towards the addictive potential for mobile phones was also high among the students. Ringxiety was also found to be common (60.5\%) among the frequent mobile phone users. In a cross-sectional survey among the medical stuff in Baystate Medical Center, an acute care hospital in Western Massachusetts, the prevalence of ringxiety
(Phantom Vibration Syndrome) among the study population was found to be $68 \%$ (95\% confidence interval $61 \%$ to $75 \%$ ). The authors concluded that Phantom vibration syndrome is common among those who use electronic devices. ${ }^{12}$ Life without a mobile phone will be boring for $70 \%$ of the students, which points towards the fact that mobile phones have become the part and parcel of modern day life and a tool for entertainment also.

Anuj Mittal et al. reported almost similar results in their study, in which nearly $73 \%$ students responded that life would be boring (54.4\%) and unsafe/lonely (18.8\%), while $26.8 \%$ considered other way; life would be happy (15.2\%), calm $(7.8 \%)$ and normal (3.9\%). ${ }^{13}$ Earache, headache and blurring of vision were the most common health related symptoms and these symptoms were significantly higher among the frequent users. Khan MM in a similar study among medical students found that impaired concentration, memory disturbances, hearing problems and insomnia were the main health problems reported by the respondents. ${ }^{14} \mathrm{Al}$-Khlaiwi T, et al. reported similar results. The results of their study showed an association between the use of mobile phones and health hazards. Headache, sleep disturbances and anxiety were the main symptoms reported by them. ${ }^{15}$

\section{RECOMMENDATIONS}

Although mobiles are part and parcels of modern day life many of the studies in the past had shown that mobile use can turn into overuse and even to the level of addiction. The current study also reemphasizes the fact. Limiting mobile phone use by increasing awareness and finding the alternative methods for recreation is the need of the hour.

\section{REFERENCES}

1. Katz JE, Akhus M. Perceptual, mobile communication, private talk, public performance. Cambridge University Press, 2002.

2. Electromagnetic field and public health: mobile phones. Geneva: World health organization; Fact Sheet No. 193 2014; p 1.

3. Electromagnetic Fields (EMF) standard and guidelines. World health organization. Available from: http//who.int/peh-emf/standards/en.

4. Puente MP, Balmori A. Addiction to cell phones: are there neurophysiological mechanisms involved? Proyecto 2007;61:8-12.

5. Johansson A, Nordin S, Heiden M, et al. Symptoms, personality traits and stress in people with mobile phonerelated symptoms and electromagnetic hypersensitivity. Journal of Psychosomatic Research 2010;68(1):37-45.

6. Korpinen LH, Pääkkönen RJ. Self-report of physical symptoms associated with using mobile phones and other electrical devices. Bioelectromagnetics 2009;30(6):431437.

7. Nomophobia is the fear of being out of mobile phone contact-and it's the plague of our 24/7 age. Evening Standard. April 1, 2008. Retrieved 2011-08-10.

8. Bragazzi NL, Puenete GD. A proposal for including nomophobia in the new DSM-V. Psychology Research and Behavior Management 2014; 7:155-160.

9. Pedrero Pérez EJ, Rodríguez Monje MT, Ruiz Sánchez De León JM. "Mobile phone abuse or addiction. A review of the literature." Adicciones 2012;24:139-152. 
10. Merlo LJ, Stone AM, Bibbey A. "Measuring problematic mobile phone use: development and preliminary psychometric properties of the PUMP Scale." J Addict 2013;Article ID 912807:p 7.

11. Dhara prajapati, Swarna Rastogi, Rachana Kapadia, et al. Usage of mobile phone among medical students in ahmadabad Gujarat. Dept of community medicine. B j Medical college, Ahmedabad, India, international journal of scientific research 2014;3(9):ISSN No 2277-8179.

12. Rothberg MB, Arora A, Hermann J, et al. Phantom vibration syndrome among medical staff: a cross sectional survey. BMJ 2010;341:c6914.
13. Anujmittal, Vedapriya DR, Lavanya K. Cell phone dependence among medical students and its implicationsa cross sectional study. Department of community medicine, aarupadaiveedu medical college, Puducherry, India. ijcrr section: healthcare sci Journal 2015;7(8):1-13.

14. Khan MM. Adverse effects of excessive mobile phone use. Int J Occup Med Environ Health 2008;21(4):289-293.

15. Al-Khlaiwi T, Meo SA. "Association of mobile phone radiation with fatigue, headache, dizziness, tension and sleep disturbance in Saudi population." Saudi Med J 2004;25:732-736. 